\title{
Exploring the Key Factors in the Use of an E-Learning System Among Students at King Faisal University, Saudi Arabia
}

\author{
https://doi.org/10.3991/ijim.v14i03.11576 \\ Ahmed Al Mulhem \\ King Faisal University, Saudi Arabia \\ ahamulhem@kfu.edu.sa
}

\begin{abstract}
The primary purpose of this study is to review and analyse the literature related to e-learning, which is linked to previous studies. Specifically, studies that used the TAM model to examine the effect of eleven external factors, such as website content quality, website design quality, website technical quality, website access speed, usability, e-learning system functionality, e-learning system reliability, facilitating conditions, top management support, student awareness and academic staff awareness on the use of an e-learning system in King Faisal University, Saudi Arabia. The findings of this study offer valuable guidelines for practitioners, researchers and educators about the most important factors that enhance the use of e-learning systems in universities.
\end{abstract}

Keywords-E-learning system, Success factors, Actual use, Saudi universities.

\section{Introduction}

In recent years, the advent of Information and Communications Technologies (ICT) has significantly influenced learning and teaching of educational systems [1]. It affected all sectors of education from schools to further, technical and higher education. Technology has proven to be essential and has positively impacted educational systems. It plays a significant role in today's university educational processes [2]. Every aspect of learning and education has been influenced by the introduction and use of technology [3]. Development of learning and education processes that is parallel with technology and communication can be divided into three stages. The first stage is distance learning, where teachers and students are separated by place and time. This learning process is done using communication technologies such as phone, radio and television. The second stage is the revolution of the internet and e-learning. At this stage, the learning process between teachers and students is done by using different forms of media such as text, hypertext, audio and video. The latest technology that has emerged is mobile learning, which is related to the use of mobile devices such as smartphones for learning purposes that forms the third stage. Some of the properties of mobile learning make it a very suitable tool to be used in education and learning in terms of providing flexible learning environments that facilitate learning anytime and anywhere $[4,48]$. Mobile 
learning is now becoming the newest technology to achieve optimum learning and education advantages $[5,45,46]$.

Because of the advancements in ICT, e-learning systems like Blackboard and Moodle have become widely recognised tools for university learning around the world. This research mainly focuses on the use of e-learning systems by students as a useful tool. E-learning systems are effectively used when there is an understanding of students' requirements and needs. Thus, this study focuses on studying the actual use of e-learning systems among students in Saudi Arabian universities. This study aims to present a group of essential factors that should be considered when implementing e-learning systems to enhance the use of e-learning systems among students in universities in Saudi Arabia. The proposed model of this research is based on the Technology Acceptance Model (TAM).

This research will examine the perceptions of students concerning the use of e-learning in the higher educational setting at King Faisal University (KFU) in Saudi Arabia. This study analyses the previous literature in the context of e-learning usage and acceptance to identify the most extensively used external factors with TAM. Consequently, this study examines the effects of eleven external factors: website content quality, website design quality, website technical quality, website access speed, usability, e-learning system functionality, e-learning system reliability, facilitating conditions, top management support, student awareness and academic staff awareness. These are looked at as independent variables on the perceived ease of use, perceived usefulness and actual use of e-learning systems as dependent variables.

Numerous studies were conducted on the adoption of e-learning systems by many $[6,7,8,9,10]$. However, there is little empirical research that focuses solely on Saudi Arabia [7,8]. Although the majority of universities in Saudi Arabia have implemented the e-learning system successfully, the percentage of e-learning system usage among teachers and students is deficient [11]. This issue underscores the goals of a study for Saudi Arabia that fills the gap in the literature and addresses the variables in a country that has a significantly distinct culture and value system. Furthermore, based on Saudi Vision 2030, Saudi Arabia is executing long-term planning to become a smart country where e-learning is not an exception.

The primary purpose of this study is to review and analyse the literature related to elearning that is linked to previous studies using the TAM model and to examine the effect of eleven external factors includes website content quality, website design quality, website technical quality, website access speed, usability, e-learning system functionality, e-learning system reliability, facilitating conditions, top management support, student awareness and academic staff awareness on the use of e-learning systems in King Faisal University, Saudi Arabia. The findings of this study will offer valuable guidelines for practitioners, researchers and educators about important factors that enhance the use of e-learning systems in universities. 
Paper-Exploring the Key Factors in the Use of an E-Learning System Among Students at King Faisal...

\section{Theoretical Background}

\subsection{Related studies on the factors impacting the adoption and usage of e- learning systems}

Several studies addressed the use and acceptance of e-learning in Saudi Arabian universities. For example, Al-Gahtani [12] investigated the factors influencing student acceptance of e-learning based on the third version of the TAM model (TAM3). He found the most significant determinants of e-learning acceptance were playfulness, self-efficacy and anxiety, while using computers, perceptions of external control, subjective norms and perceived usefulness. However, in the context of Saudi Arabia, social influence, demonstrability and perceived enjoyment were not related to the acceptance of elearning systems.

Naveed et al. [13] suggested that technological readiness with system characteristics were significant factors impacting the acceptance of e-learning. Alharbi, Sandhu and Brown [14] found that service quality and student/instructor interactions with computers were sufficient with extended use of e-learning systems in Saudi Arabia. Similarly, Alhabeeb and Rowley [6] found that academic staff knowledge of learning technologies, student knowledge of computer systems and technical infrastructure, were significant factors in facilitating the successful acceptance of e-learning in Saudi Arabian universities.

A survey conducted on 257 respondents at Saudi Arabian universities investigated the acceptance and usage of e-learning [10]. The results indicated that infrastructure and technology decisions made during the implementation process were important in motivating students to use and accept e-learning systems. Abdullah and Ward [15] also investigated factors influencing e-learning acceptance using TAM. Their findings revealed that self-efficacy, subjective norms, enjoyment, anxiety and experience with using computers had a significant effect on students' acceptance of e-learning.

Alharthi et al., [8] investigated factors that influence faculty members' acceptance and use of e-learning systems at Saudi universities. They found that self-efficacy with computer usage, user satisfaction and user resistance, were strong factors related to elearning acceptance. Bellaaj, Zekri and Albugami [16] used the Unified Theory of Acceptance and Use of Technology (UTAUT) model to explore the factors affecting students' use of e-learning systems at the University of Tabuk, Saudi Arabia. They found that expectations regarding performance and effort had a strong influence on e-learning acceptance. In another study in Azerbaijan, Chang, Hajiyev and Su [17] found subjective norms, experience and enjoyment influenced acceptance of e-learning.

Sumak et al. [18] conducted a meta-analysis of the causal effect sizes between current TAM-related relationships. Their study revealed that TAM was the most commonly used acceptance theory in e-learning acceptance research. They also found that the size of causal effects between individual TAM-related factors depended on the type of user and e-learning technology. User-related factors such as employees, students, and teachers or professors, technology-related factors, e-learning systems and other elearning technologies or tools, displayed moderate effects on several of the evaluated causal paths. 
Selim [19] surveyed 538 university students to examine four categories of e-learning success factors including instructor, student, information technology and university support. The survey revealed eight successful categories and each of these included several critical e-learning acceptance and success measures. The importance of the measures contained in each success factor was tested using a confirmatory factor modelling approach. Bhuasiri et al. [20] highlighted success factors for e-learning in developing countries by using the Delphi method and the Analytic Hierarchy Process. Six dimensions and 20 success factors were found. The most critical factors were curriculum design for learning performance, technology awareness, motivation and changing learners' behaviour.

Meanwhile, Chen [21] investigated the influence of student expectations towards technology and their educational compatibility on their acceptance of e-learning using UTAUT. He collected data from 626 students and found that both factors affected elearning acceptance. However, he concluded that educational compatibility had more influence than technology expectations.

Alenezi et al. [22] explored institutional support and student e-learning acceptance in five Saudi universities using TAM. They found that three variables significantly contributed to student acceptance of e-learning: facilitating conditions, training and institutional and technical support. Sánchez and Hueros [23] found similar results in terms of technical support having a direct influence on perceived ease of use and usefulness. They tested Moodle usage and found it to be positively influenced by perceived ease of use and attitude.

Tarhini et al. [24] believed that decision-makers should consider critical success factors related to individual, social and institutional factors when implementing e-learning systems. The authors administered a cross-sectional survey to 604 students using elearning systems at Brunel University in England. The study results illustrated that perceived ease of use, perceived usefulness, social norms, quality of work life, self-efficacy with computers and facilitating conditions played a significant role in the adoption and usage of the Blackboard system.

Lee et al. [25] studied four new factors - instructor characteristics, teaching materials, the design of learning contents and playfulness. They found instructor characteristics and teaching materials to be positively related to perceived usefulness; the design of learning contents was positively related to perceived ease of use and playfulness positively affected the intention to use e-learning systems. A study by Islam [26] reported that perceived learning assistance and perceived community-building assistance were both impacted by student beliefs regarding perceived usefulness and ease of use, as well as how an e-learning system was used. In turn, perceived learning assistance and perceived community-building assistance influenced students' perceived academic performance.

\subsection{E-learning and Technology Adoption Models}

According to the literature, many theories and models were developed by scholars and researchers to examine users' acceptance of new technologies and their intention to use them. Each model and theory were adopted, modified and validated by other 
researchers to gain insight and predict technology acceptance and usage [27]. For example, TAM was developed by Davis [28] and was improved on by Venkatesh who created TAM2 [27]. And TRA was developed by Ajzen and Fishbein [29] and developed into TBP by Ajzen [30].

Many researchers conducted a comparative analysis between the most suitable models. The aim was to determine the most relevant models and theories with sound theoretical and empirical bases that met the research purpose and ignored other models [27]. Based on this, the current study conducted a review of the most robust models that were significant in describing IT/IS adoption behaviour. Each model is explained in detail in the following sections, followed by the primary justification for using a specific model for this study.

Theory of Reasoned Action (TRA). The first theoretical model developed to study technology adoption research was TRA [31]. It became one of the most widely accepted and was used by IT researchers to predict and understand an individual's behaviour. The theory was developed to explain and predict IT usage behaviour across a broad range of domains. Ajzen [30] extended the theory by including an additional construct: Perceived Behavioural Control (PBC). The construct was useful in predicting both behavioural intentions to use as well as actual user behaviour. And the extended model was called the Theory of Planned Behaviour (TPB).

The Unified Theory of Acceptance and Use of Technology (UTAUT). This model was developed by Venkatesh et al. [27], which was used in recent years only by some researchers. UTAUT consists of four core determinants of intention and usage and up to four moderators of critical relationships. The four core determinants consist of: i) performance expectancy, ii) effort expectancy, iii) social influence and iv) facilitating conditions being the direct determinant of behavioural intention of the user. Other than these four constructs, the relationship is moderated by individual differences in terms of gender, age, experience and voluntariness (ibid). After reviewing the UTAUT, Venkatesh and Zhang [32] removed the voluntariness construct as one of the moderating variables, keeping only three constructs. However, they added three direct constructs: hedonic motivation, price value and habit in what they called UTAUT2. Tarhini et al. [24] suggested the UTAUT model did not provide as much insight into the adoption of e-government services. UTAUT as a model cannot be used in all studies as it is considered complicated, which leaves it open to criticism by many experts [33].

Technology Acceptance Model (TAM). TAM was developed from the TRA by Davis [28], who designed and validated better measures through TAM to predict and explain technology adoption and use. The original TAM composed of three main variables as shown in Figure 1: Perceived Usefulness (PU), Perceived Ease of Use (PEOU) and Behavioural Intention (BI) that predict the use of technology. And also two primary keys: PU and PEOU, otherwise known as extrinsic factors that motivate users' acceptance, adoption and usage behaviour of new technology [34].

TAM, as defined by Davis [28], is the most common technology acceptance model used by researchers in the IT/IS field. For example, Surendran [35] claimed that TAM is the best research model to predict the use and acceptance of information systems and technology by individual users. According to Almaiah, Jalil and Man [36], it is one of the most potent models used in studies on determinants of IS/IT acceptance, and it is 
one of the most influential research models to determine the level of IS adoption at an individual level. TAM is considered a simple model that is easy to use by many researchers, which is the reason it is still attractive today. However, the basic model of TAM neglects some relevant elements and causal factors that possess a direct effect on the adoption of e-learning systems. Because of this, it was criticised by many researchers working in this field, e.g., Almaiah and Alismaiel [37]; Almaiah and Almulhem [38].

Justifying TAM as the theoretical foundation in this study. This section will offer a justification for the use of TAM as a model for technology adoption and usage appropriate to e-learning systems, and hence its application to this study. The critique in this section is based upon the existing analysis of literature regarding the suitability of TAM. The researcher compared TAM to other important models in the field of adoption technologies. According to the literature, TAM has the upper explanatory power when compared to other relevant models and theories in the context of IS/IT adoption. According to Cheng [39], TAM is the most popular model in the field of technology adoption and focuses on technological factors of successful implementation of information systems. The is also reflected in other studies. Almaiah [5], for example, stated that TAM is one of the most popular research models to predict the use and acceptance of information systems and technology by students in educational settings. This is based on certain factors that can be used with it.

According to many studies $[17,40]$, TAM proved to be a valid model for explaining and predicting students' usage and adoption behaviour regarding the use of e-learning systems in universities. Also, TAM has received a high level of attention in literature compared to other models such as TRA, TAM and UTAUT [17]. TAM is still considered more efficient and it has higher explanatory power when compared to other models [5]. Most researchers used TAM to test new technologies based on two beliefs-PU and PEOU—as crucial for technology adoption and usage behaviour [17]. Hence, the researcher selected TAM to develop a conceptual model for this study to achieve a solid base to explain why students accept or reject e-government systems. Based on that, TAM forms the theoretical foundation of the proposed research model for this study. 


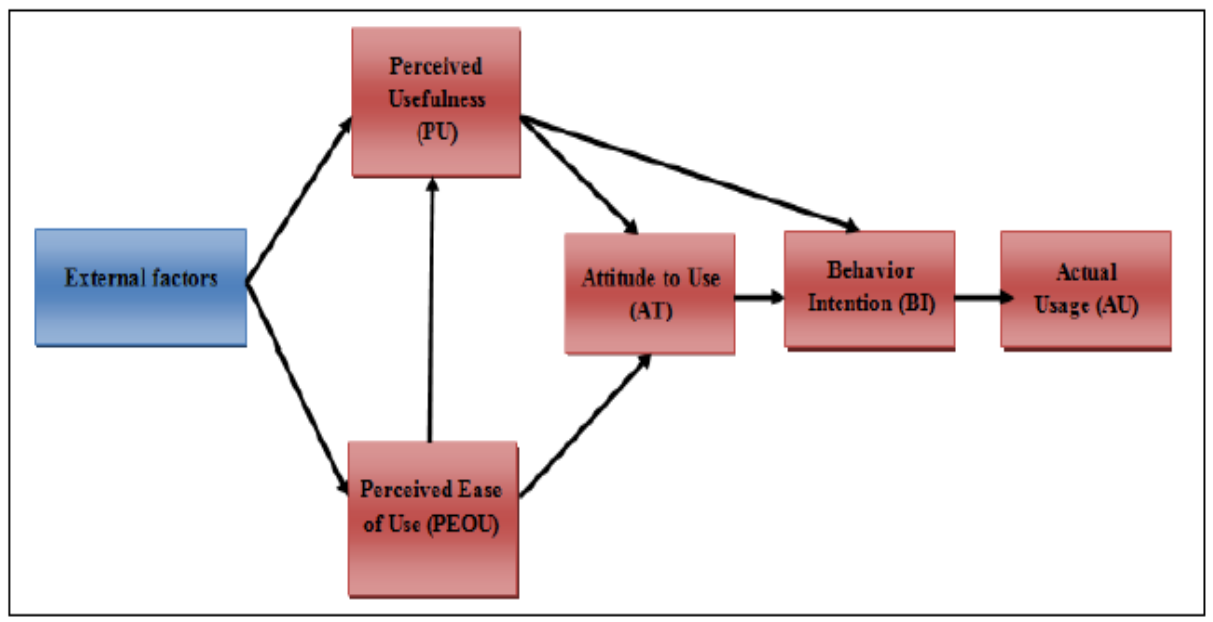

Fig. 1. Technology Acceptance Model [28]

\subsection{Proposed research model and hypothesis}

Based on the literature, TAM is considered a valid and robust model that is used extensively. However, it applies to an even broader context. To assess the conditions under which TAM may exhibit different outcomes, a moderator analysis of user types and usage types was carried out. It was subsequently deduced that students may be used as substitutes for professionals in specific TAM studies, and possibly even in a general context. These results may offer information to researchers and educators regarding the research trends of e-learning.

Also, the literature revealed that website content quality, website design quality, website technical quality, website access speed, usability, e-learning system functionality, e-learning system reliability, facilitating conditions, top management support, student awareness and academic staff awareness were considered the most extensively used external factors. Consequently, in this study the research model and research hypotheses were developed to test the relationship between these eleven external factors and TAM's variables (PEOU, PU, and AU), as shown in Figure 2. The definitions of all constructs and hypotheses in the research model are illustrated in Table 1. 


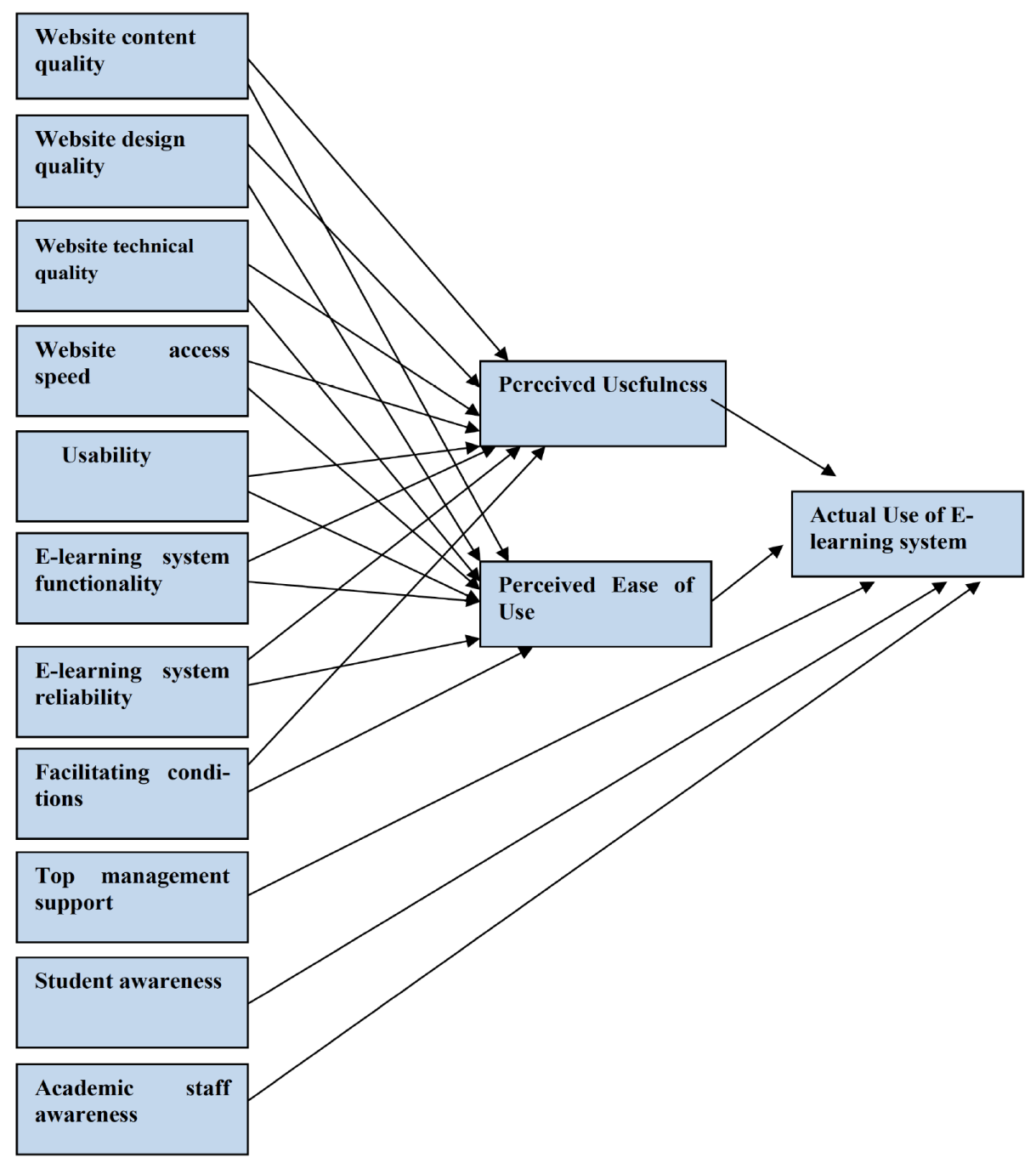

Fig. 2. The proposed research model 
Paper-Exploring the Key Factors in the Use of an E-Learning System Among Students at King Faisal..

Table 1. Conceptual definitions of all constructs and hypotheses.

\begin{tabular}{|c|c|c|}
\hline Constructs & Conceptual definitions & Hypotheses \\
\hline $\begin{array}{l}\text { Website Con- } \\
\text { tent Quality } \\
\text { (WCQ) }\end{array}$ & $\begin{array}{l}\text { The content of e-learning materials must be pre- } \\
\text { cise, accurate, updated, timely and suitable. The } \\
\text { website must offer exact and useful learning con- } \\
\text { tent that allows learners to find and carry out their } \\
\text { learning activities without difficulty. }\end{array}$ & $\begin{array}{l}\text { H1a: Website content quality has a } \\
\text { positive relationship with perceived } \\
\text { usefulness of e-learning systems } \\
\text { H1b: Website Content Quality has a } \\
\text { positive relationship with perceived } \\
\text { ease of use of e-learning systems }\end{array}$ \\
\hline $\begin{array}{l}\text { Website De- } \\
\text { sign Quality } \\
\text { (WDQ) }\end{array}$ & $\begin{array}{l}\text { The content design of e-learning materials refers } \\
\text { to aesthetics such as the use of colour and appeal- } \\
\text { ing multimedia features, and must also support } \\
\text { several types of learning content that meet stu- } \\
\text { dents' requirements. }\end{array}$ & $\begin{array}{l}\text { H2a: Website design quality has a pos- } \\
\text { itive relationship with perceived useful- } \\
\text { ness of e-learning systems } \\
\text { H2b: Website design quality has a pos- } \\
\text { itive relationship with perceived ease of } \\
\text { use of e-learning systems }\end{array}$ \\
\hline $\begin{array}{l}\text { Website } \\
\text { Technical } \\
\text { Quality } \\
\text { (WTQ) }\end{array}$ & $\begin{array}{l}\text { This factor concentrates on the degree of availabil- } \\
\text { ity of the essential infrastructure technology re- } \\
\text { quirements that support the e-learning system and } \\
\text { indicates whether the current infrastructure can ac- } \\
\text { commodate such a system. }\end{array}$ & $\begin{array}{l}\text { H3a: Website Technical Quality has a } \\
\text { positive relationship with perceived } \\
\text { usefulness of e-learning systems } \\
\text { H3b: Website Technical Quality has a } \\
\text { positive relationship with perceived } \\
\text { ease of use of e-learning systems }\end{array}$ \\
\hline $\begin{array}{l}\text { Website Ac- } \\
\text { cess Speed } \\
\text { (WAS) }\end{array}$ & $\begin{array}{l}\text { Website access speed refers to the satisfaction } \\
\text { level that students experience towards fast re- } \\
\text { sponse times of their e-learning system. This in- } \\
\text { cludes both execution time and delivery time of } \\
\text { service via an e-learning portal. }\end{array}$ & $\begin{array}{l}\text { H4a: Website Access Speed has a posi- } \\
\text { tive relationship with perceived useful- } \\
\text { ness of e-learning systems } \\
\text { H4b: Website Access Speed has a posi- } \\
\text { tive relationship with perceived ease of } \\
\text { use of e-learning systems }\end{array}$ \\
\hline Usab & $\begin{array}{l}\text { The degree to which students see that the e-learn- } \\
\text { ing system is easy to use, easy to learn and easy to } \\
\text { understand. }\end{array}$ & $\begin{array}{l}\text { H5a: Usability has a positive relation- } \\
\text { ship with perceived usefulness of e- } \\
\text { learning systems } \\
\text { H5b: Usability has a positive relation- } \\
\text { ship with perceived ease of use of e- } \\
\text { learning systems }\end{array}$ \\
\hline $\begin{array}{l}\text { E-learning } \\
\text { System Func- } \\
\text { tionality (FN) }\end{array}$ & $\begin{array}{l}\text { The degree to which learners see the overall func- } \\
\text { tional benefits including time, efficiency and ef- } \\
\text { fectiveness of using e-learning systems. }\end{array}$ & $\begin{array}{l}\text { H6a: System Functionality has a posi- } \\
\text { tive relationship with perceived useful- } \\
\text { ness of e-learning systems } \\
\text { H6b: System Functionality has a posi- } \\
\text { tive relationship with perceived ease of } \\
\text { use of e-learning systems }\end{array}$ \\
\hline $\begin{array}{l}\text { E-learning } \\
\text { System Relia- } \\
\text { bility (RE) }\end{array}$ & $\begin{array}{l}\text { A learner's confidence in the e-learning system's } \\
\text { ability to provide a reliable and efficient service. }\end{array}$ & $\begin{array}{l}\text { H7a: System Reliability has a positive } \\
\text { relationship with perceived usefulness } \\
\text { of e-learning systems } \\
\text { H7b: System Reliability has a positive } \\
\text { relationship with perceived ease of use } \\
\text { of e-learning systems }\end{array}$ \\
\hline $\begin{array}{l}\text { Facilitating } \\
\text { Conditions } \\
(\mathrm{FC})\end{array}$ & $\begin{array}{l}\text { A learner's perception of disposable resources and } \\
\text { support when performing learning activities. }\end{array}$ & $\begin{array}{l}\text { H7a: Facilitating Conditions has a pos- } \\
\text { itive relationship with perceived useful- } \\
\text { ness of e-learning systems } \\
\text { H7b: Facilitating Conditions has a pos- } \\
\text { itive relationship with perceived ease of } \\
\text { use of e-learning systems }\end{array}$ \\
\hline $\begin{array}{l}\text { Top Manage- } \\
\text { ment Support } \\
\text { (TMS) }\end{array}$ & $\begin{array}{l}\text { The degree to which senior management believe } \\
\text { in and understand the importance of e-learning } \\
\text { systems, learning processes and the benefits of e- } \\
\text { learning systems for both students and teachers. }\end{array}$ & $\begin{array}{l}\text { H8: Top Management Support has a } \\
\text { positive relationship with the actual use } \\
\text { of e-learning systems }\end{array}$ \\
\hline
\end{tabular}




\begin{tabular}{|l|l|l|}
\hline $\begin{array}{l}\text { Student } \\
\text { Awareness } \\
\text { (SA) }\end{array}$ & $\begin{array}{l}\text { The degree of students' consciousness through ac- } \\
\text { quiring knowledge to be sufficient to learn the } \\
\text { characteristics of e-learning systems, to use them } \\
\text { with skill and realise its functions, advantages and } \\
\text { disadvantages. }\end{array}$ & $\begin{array}{l}\text { H9: Student Awareness has a positive } \\
\text { relationship with the actual use of e- } \\
\text { learning systems }\end{array}$ \\
\hline $\begin{array}{l}\text { Academic } \\
\text { Staff Aware- } \\
\text { ness (ASA) }\end{array}$ & $\begin{array}{l}\text { The degree of teachers' consciousness through ac- } \\
\text { quiring knowledge to be sufficient to learn the } \\
\text { characteristics of e-learning systems, to use them } \\
\text { with skill and realise its functions, advantages and } \\
\text { disadvantages. }\end{array}$ & $\begin{array}{l}\text { H10: Academic Staff Awareness has a } \\
\text { positive relationship with the actual use } \\
\text { of e-learning systems }\end{array}$ \\
\hline $\begin{array}{l}\text { Perceived } \\
\text { Usefulness } \\
\text { (PU) }\end{array}$ & $\begin{array}{l}\text { The degree of which the students find the system } \\
\text { is useful for them }\end{array}$ & $\begin{array}{l}\text { H11: Perceived Usefulness has a posi- } \\
\text { tive relationship with the actual use of } \\
\text { e-learning systems }\end{array}$ \\
\hline $\begin{array}{l}\text { Perceived } \\
\text { Ease of Use } \\
\text { (PEU) }\end{array}$ & $\begin{array}{l}\text { The degree of which the students find the system } \\
\text { is free of effort }\end{array}$ & $\begin{array}{l}\text { H12a: Perceived Ease of Use has a } \\
\text { positive relationship with perceived } \\
\text { usefulness of e-learning systems } \\
\text { H12b: Perceived Ease of Use has a } \\
\text { positive relationship with the actual use } \\
\text { of e-learning systems }\end{array}$ \\
\hline
\end{tabular}

\section{Research Methodology}

\subsection{Research Questionnaire Development}

In this research, a survey questionnaire was designed to determine what influences students' usage of e-learning systems at King Faisal University. The questionnaire contained 30 questions and eleven variables. The questions were derived from previous studies to ensure content validity. For example, Website Content Quality (WCQ), Website Design Quality (WDQ), Website Technical Quality (WTQ), Website Access Speed (WAS) and Usability (U) were adopted from Almaiah and Man [40]. System Functionality (FN), System Reliability (RE) and Facilitating Conditions (FC) were adopted from Cheng [17]. Top Management Support (TMS), Student Awareness (SA) and Academic Staff Awareness (ASA) were adopted from Almaiah and Almulhem [41]. The questionnaire included five questions to identify the demographics of each participant. The questionnaire was also translated into the Arabic language to avoid confusion. It used a five-point Likert scale ranging from 'Strongly Disagree' to 'Strongly Agree'. The five-point Likert scale was considered more accurate than the three-point scale [42].

\subsection{Respondents}

As stated by Hair et al. [44], the sample should represent the population and must contain a sufficient number of respondents. When the number of participants is higher, it produces greater validity and more reliable results. According to Sekaran and Bougie [43], researchers can decide the size of the sample based on the population. In this study, a large number of participants were sought to obtain an optimal sample-size. The resulting sample of 380 students provided a more accurate analysis [44]. Using 380 students accurately reflected students' opinions, expectations, satisfaction and usage of 
e-learning systems [44]. Three hundred and eighty questionnaires were distributed to students from educational technology departments by researchers at King Faisal University. Three hundred and twenty completed questionnaires were collected resulting in a response rate of $84 \%$.

\section{$4 \quad$ Analysis of Data and Results}

\subsection{Respondents' demographic profile}

The profile background of the respondents was formed based on gender, age, level of study and internet use. The profile background is summarised in Table 2 . The respondents consisted of $92.8 \%$ female and $7.2 \%$ male. $59.3 \%$ were between $18-20$ years old and $40.7 \%$ were between $32-42$ years old. All respondents were studying at undergraduate level at the time of this research. $98.6 \%$ of respondents claimed to use the internet several times a day.

Table 2. Respondents' demographic profile

\begin{tabular}{|c|c|c|c|}
\hline & Classification & Frequency & Percent \\
\hline \multirow{2}{*}{ Gender } & Female & 297 & $92.8 \%$ \\
\cline { 2 - 4 } & Male & 33 & $7.2 \%$ \\
\hline \multirow{2}{*}{ Level of study } & $18-20$ & 110 & $59.3 \%$ \\
\cline { 2 - 4 } & $20-22$ & 132 & $40.7 \%$ \\
\cline { 2 - 4 } & Undergraduate & 320 & $100 \%$ \\
\hline \multirow{2}{*}{ Iepartment } & Postgraduate & 0 & $0 \%$ \\
\cline { 2 - 4 } & Educational Technology & 320 & $100 \%$ \\
\cline { 2 - 4 } & Other & 0 & $0 \%$ \\
\cline { 2 - 4 } & Never used & 0 & $0.0 \%$ \\
\cline { 2 - 4 } & Several times weekly & 10 & $1.4 \%$ \\
\cline { 2 - 4 } & Several times every day & 310 & $98.6 \%$ \\
\hline
\end{tabular}

\subsection{Reliability analysis}

Before conducting the primary analysis the research instrument was verified. A reliability analysis measured the consistency between items in the same construct using Cronbach's Alpha. Hair et al. [44] stated that a value of above 0.7 was required to be classed as highly reliable, and values between 0.6 and 0.7 were deemed to be acceptable. Table 3 shows the reliability values for all constructs, which was higher than 0.7 . Therefore, the questionnaire was considered reliable at the time of research. 
Paper-Exploring the Key Factors in the Use of an E-Learning System Among Students at King Faisal..

Table 3. Results of reliability and convergent validity analysis

\begin{tabular}{|l|c|c|}
\hline \multicolumn{1}{|c|}{ Constructs } & $\begin{array}{c}\text { Cronbach's Alpha } \\
(\boldsymbol{\alpha}>\mathbf{0 . 7})\end{array}$ & $\begin{array}{c}\text { Average Variance Extracted } \\
(\mathbf{A V E} \mathbf{0 . 5 )}\end{array}$ \\
\hline Website Content Quality (WCQ) & 0.93 & 0.78 \\
\hline Website Design Quality (WDQ) & 0.90 & 0.75 \\
\hline Website Technical Quality (WTQ) & 0.88 & 0.73 \\
\hline Website Access Speed (WAS) & 0.83 & 0.65 \\
\hline Usability (U) & 0.85 & 0.68 \\
\hline System Functionality (FN) & 0.81 & 0.60 \\
\hline System Reliability (RE) & 0.87 & 0.71 \\
\hline Facilitating Conditions (FC) & 0.89 & 0.74 \\
\hline Top Management Support (TMS) & 0.87 & 0.77 \\
\hline Student Awareness (SA) & 0.85 & 0.75 \\
\hline Academic Staff Awareness (ASA) & 0.83 & 0.72 \\
\hline Perceived Usefulness (PU) & 0.91 & 0.79 \\
\hline Perceived Ease of Use (PEU) & 0.89 & 0.78 \\
\hline Actual Use (AU) & 0.92 & 0.79 \\
\hline
\end{tabular}

\subsection{Convergent and Discriminant Validity Analysis}

The validity of constructs was assessed for convergent validity and discriminant validity. For the convergent validity, the results in Table 3 show that the average variance extracted (AVE) was above 0.5 . For the discriminant validity analysis, the square root of AVE was taken to correlate the latent constructs. Table 4 shows the square root of the AVE for all constructs is higher than the pairwise correlations. Therefore, the psychometric characteristics of the instrument were acceptable in terms of discriminant validity [44]

Table 4. Discriminant validity analysis

\begin{tabular}{|c|c|c|c|c|c|c|c|c|c|c|c|c|c|c|}
\hline Variables & $\begin{array}{c}\text { WC } \\
\mathbf{Q}\end{array}$ & $\begin{array}{c}\text { WD } \\
\mathbf{Q}\end{array}$ & $\begin{array}{c}\text { WT } \\
\mathbf{Q}\end{array}$ & $\mathbf{W A S}$ & $\mathbf{U}$ & $\mathbf{F N}$ & $\mathbf{R E}$ & FC & TMS & SA & ASA & PU & PEU & AU \\
\hline $\begin{array}{c}\text { Website Con- } \\
\text { tent Quality } \\
\text { (WCQ) }\end{array}$ & $\mathbf{0 . 8 9}$ & & & & & & & & & & & & & \\
\hline $\begin{array}{c}\text { Website De- } \\
\text { sign Quality } \\
\text { (WDQ) }\end{array}$ & .445 & $\mathbf{0 . 9 1}$ & & & & & & & & & & & & \\
\hline $\begin{array}{c}\text { Website } \\
\text { Technical } \\
\text { Quality } \\
\text { (WTQ) }\end{array}$ & .482 & .377 & $\mathbf{0 . 8 7}$ & & & & & & & & & & & \\
\hline $\begin{array}{c}\text { Website Ac- } \\
\text { cess Speed } \\
\text { (WAS) }\end{array}$ & .473 & .560 & .439 & $\mathbf{0 . 8 2}$ & & & & & & & & & & \\
\hline Usability (U) & .384 & .445 & .445 & .473 & $\mathbf{0 . 8 0}$ & & & & & & & & & \\
\hline
\end{tabular}


Paper-Exploring the Key Factors in the Use of an E-Learning System Among Students at King Faisal...

\begin{tabular}{|c|l|l|l|l|l|l|l|l|l|l|l|l|l|l|}
\hline $\begin{array}{c}\text { System Func- } \\
\text { tionality (FN) }\end{array}$ & .566 & .408 & .482 & .408 & .377 & $\mathbf{0 . 9 0}$ & & & & & & & & \\
\hline $\begin{array}{c}\text { System Relia- } \\
\text { bility (RE) }\end{array}$ & .338 & .502 & .473 & .445 & .560 & .377 & $\mathbf{0 . 8 6}$ & & & & & & & \\
\hline $\begin{array}{c}\text { Facilitating } \\
\text { Conditions } \\
\text { (FC) }\end{array}$ & .408 & .384 & .408 & .408 & .445 & .560 & .482 & $\mathbf{0 . 8 1}$ & & & & & & \\
\hline $\begin{array}{c}\text { Top Manage- } \\
\text { ment Support } \\
\text { (TMS) }\end{array}$ & .502 & .566 & .502 & .502 & .482 & .473 & .473 & .502 & $\mathbf{0 . 8 8}$ & & & & & \\
\hline $\begin{array}{c}\text { Student } \\
\text { Awareness } \\
\text { (SA) }\end{array}$ & .463 & .338 & .533 & .445 & .473 & .377 & 0.772 & .384 & .502 & $\mathbf{0 . 8 5}$ & & & & \\
\hline $\begin{array}{c}\text { Academic } \\
\text { Staff Aware- } \\
\text { ness (ASA) }\end{array}$ & .377 & 445 & .515 & .408 & .445 & .560 & .384 & 04.83 & .291 & .445 & $\mathbf{0 . 8 7}$ & & & \\
\hline $\begin{array}{c}\text { Perceived } \\
\text { Usefulness } \\
\text { (PU) }\end{array}$ & .560 & .482 & .455 & .502 & .408 & .445 & .566 & .301 & 04.75 & .408 & .377 & $\mathbf{0 . 7 4}$ & \\
\hline $\begin{array}{c}\text { Perceived } \\
\text { Ease of Use } \\
\text { (PEU) }\end{array}$ & .473 & .473 & .459 & .291 & .502 & .408 & .338 & .345 & .421 & .502 & .560 & .445 & $\mathbf{0 . 8 7}$ \\
\hline $\begin{array}{c}\text { Actual Use } \\
\text { (AU) }\end{array}$ & .445 & .560 & .463 & .338 & .533 & .445 & .463 & .338 & .445 & .560 & .482 & 445 & .515 & $\mathbf{0 . 8 3}$ \\
\hline
\end{tabular}

\subsection{Research Model Testing}

The model testing involved determining how well suited the research instrument was to the study data. For this study, the Goodness of Fit (GoF) method was used. [43] believed that GoF is an important stage of testing. In this study, a Confirmatory Factor Analysis (CFA) was used to identify the model-fit indices of the research model, as shown in Table 5.

Table 5. Model fit indices analysis

\begin{tabular}{|c|c|c|}
\hline Fit index & Research model & Recommended values \\
\hline $\mathrm{x}^{2} /$ d.f. & 4.01 & $<5.00$ \\
\hline GFI & 0.921 & $>0.90$ \\
\hline AGFI & 0.876 & $>0.80$ \\
\hline RMSEA & 0.033 & $<0.06$ \\
\hline SRMR & 0.072 & $<0.08$ \\
\hline NFI & 0.932 & $>0.90$ \\
\hline NNFI & 0.941 & $>0.90$ \\
\hline CFI & 0.923 & $>0.90$ \\
\hline IFI & 0.911 & $>0.90$ \\
\hline
\end{tabular}

Following confirmation of the model's suitability, the Structural Equation Modelling (SEM) analysis was carried out with SmartPLS version 3.0. Next section displays the 
data obtained from hypotheses testing. In total, nineteen hypotheses were proposed to examine the effects of website content quality, website design quality, website technical quality, website access speed, usability, system functionality, system reliability, facilitating conditions, top management support, student awareness, academic staff awareness and TAM's variables (PEOU, PU, and AU).

\section{Discussion}

Several studies were conducted on the usage and adoption of e-learning systems by many researchers $[5,6,7,8,9]$. However, there was little empirical research that focused solely on Saudi Arabia [6,7,41]. Although the majority of universities in Saudi Arabia implemented the e-learning system successfully, the percentage of use of e-learning systems among teachers and students was deficient [41]. This influenced the current study; to fill the gap in the literature. The researcher developed a comprehensive model based on the review and analysis of studies related to e-learning. In particular, studies that used TAM to examine the effect of eleven external factors: website content quality, website design quality, website technical quality, website access speed, usability, elearning system functionality, e-learning system reliability, facilitating conditions, top management support, student awareness and academic staff awareness on TAM's variables (PEOU, PU, and AU) were examined. This was done to identify the critical factors that motivated students to use the e-learning system at King Faisal University. In this section, the findings of this study will be discussed and will offer important information for practitioners, researchers and educators regarding important factors that enhance the use of e-learning systems in universities.

This study incorporated website content quality (WCQ), website design quality (WDQ), website technical quality (WTQ) and website access speed (WAS) as independent variables into TAM. Based on the hypotheses, this research aimed to examine the effects of website content quality, website design quality, website technical quality and website access speed on actual use of e-learning systems through perceived usefulness and perceived ease of use.

The results revealed a positive relationship between website content quality and website design quality with perceived usefulness and perceived ease of use of e-learning systems (H1a, $\boldsymbol{\beta}=0.480, \mathbf{p}<0.001, \mathbf{H 1 b}, \boldsymbol{\beta}=0.471, \mathrm{p}<0.001)$ and $(\mathbf{H 2 a}, \boldsymbol{\beta}=0.504$, $\mathrm{p}<0.001, \mathbf{H 2} \mathbf{b}, \beta=0.513, \mathrm{p}<0.001)$. This implies that if e-learning systems offer effective learning content, accurate learning materials and provide up-to-date courses, students will perceive the e-learning system as useful to their learning and ease of use. This will, in turn, lead to an increase in the use of e-learning systems. The result is consistent with work carried out on mobile learning by Almaiah, Jalil and Man [36]. They found that learning content quality was the main determinant of perceived usefulness and ease of use. Also, this indicates that website design quality is among the primary factors for promoting the convenience and ease of use of e-learning systems. Hence, when e-learning systems support several types of learning content that meet students' requirements, it will motivate them to use them. The findings also reveal that website technical quality 
and website access speed have a positive effect on the perceived usefulness of e-learning systems with coefficients (H3a, $\beta=0.432, \mathrm{p}<0.001, \mathbf{H 4 a}, \beta=0.417, \mathrm{p}<0.001)$. This result indicates that website technical quality and website access are critical for improving the use of e-learning systems. Also, the study found insignificant effects of website technical quality and website access speed regarding the ease of use of e-learning systems $(\mathbf{H 3} \mathbf{b}, \beta=0.012, \mathrm{p}>0.001$, and $\mathbf{H} 4 \mathbf{b}, \beta=0.022, \mathrm{p}>0.001)$. These results are consistent with previous studies $[17,36]$.

This research also examined the effects of system functionality (FN), system reliability (RE) and facilitating conditions (FC) on the actual use of e-learning through perceived usefulness and ease of use. The results revealed a strong relationship between system functionality, system reliability and facilitating conditions with perceived usefulness and ease of use. This suggests that when students perceive e-learning systems as offering the necessary features that enable them to do their learning activities effectively and easily, it will enhance their use of it. This result supports hypotheses H5a and H5b with coefficients (H5a, $\boldsymbol{\beta}=0.462, \mathrm{p}<0.001, \mathbf{H 5 b}, \boldsymbol{\beta}=0.431, \mathrm{p}<0.001)$. Another finding was e-learning systems providing reliable and efficient learning activities, which will lead to an increase in trust among students towards this system, thus, enhancing the usage of e-learning systems. These findings support hypotheses H6a, H6b (H6a, $\boldsymbol{\beta}=0.421, \mathrm{p}<0.001, \mathbf{H 6 b}, \boldsymbol{\beta}=0.407, \mathrm{p}<0.001)$ and H7a and H7b $(\mathbf{H} 7 \mathbf{a}, \boldsymbol{\beta}=0.411$, $\mathrm{p}<0.001, \mathbf{H} 7 \mathbf{b}, \boldsymbol{\beta}=0.403, \mathrm{p}<0.001)$. This result is consistent with previous studies conducted by $[17,36]$.

Other findings included top management support factors playing a crucial role in enhancing the usage of e-learning systems among academic staff in universities, which supports $\mathbf{H 8}(\mathbf{H 8}, \boldsymbol{\beta}=0.537, \mathrm{p}<0.001)$. In this case, academic staff will encourage students to use the e-learning system. In addition, management support ensures that academic staff are sufficiently trained to use e-learning systems [5,6,36], which, in turn, reduces academic load and allows faculty to learn and adapt to them $[5,6]$.

This research tested the effects of student and academic staff awareness on the actual use of e-learning systems. The findings revealed that the awareness factor has a significant impact on the actual use of e-learning systems for both students and academic staff with coefficients $(\mathbf{H 9}, \boldsymbol{\beta}=0.441, \mathrm{p}<0.001, \mathbf{H 1 0}, \boldsymbol{\beta}=0.453, \mathrm{p}<0.001)$. This suggests that when academic faculty and students have the necessary knowledge about how to use the e-learning tool as well as the main advantages of the system, the use of it will increase for both. Therefore, raising the awareness of educational staff awareness and students is considered one of the important factors in enhancing the usage of e-learning systems in a university environment. This result is consistent with $[5,6]$.

\section{Conclusion}

This research adds to the existing research into e-learning system usage and adoption. An adapted TAM model was used to identify the factors that affect students' actual use of e-learning systems in King Faisal University, Saudi Arabia. Firstly, the results show that website content quality, website design quality, usability, system functional- 
ity, system reliability, facilitating conditions, top management support, student awareness and academic staff awareness were significant determinants of usefulness and ease of use. This suggests that website content quality, website design quality, usability, system functionality, system reliability and facilitating conditions are influential in the usage and adoption of e-learning systems. Secondly, regarding the TAM model constructs, the results indicate that perceived usefulness and perceived ease of use all contribute to the actual use of e-learning systems. Thirdly, website technical quality and website access speed factors are not shown to be significant to ease of use. Lastly, the effect of top management support, student awareness and academic staff awareness on the actual use of e-learning systems were significant for Saudi students. This suggests that when awareness increases, students and academic staff are more willing to use elearning systems.

\section{$7 \quad$ References}

[1] Almaiah, M. A., \& Al Mulhem, A. (2018). Analysis of the essential factors affecting of intention to use of mobile learning applications: A comparison between universities adopters and non-adopters. Education and Information Technologies, 1-36. https://oi.org/10.1 007/s10639-018-9840-1

[2] Abdullah, F., \& Ward, R. (2016). Developing a General Extended Technology Acceptance Model for E-Learning (GETAMEL) by analysing commonly used external factors. Computers in Human Behavior, 56, 238-256. https://doi.org/10.1016/j.chb.2015.11.036

[3] Almaiah, M. A. (2018). Acceptance and usage of a mobile information system services in University of Jordan. Education and Information Technologies, 1-23.

[4] Almaiah, M. A., \& Alismaiel, O. A. (2019). Examination of factors influencing the use of mobile learning system: An empirical study. Education and Information Technologies, 24(1), 885-909. https://doi.org/10.1007/s10639-018-9810-7

[5] Adelson, J. L., \& McCoach, D. B. (2010). Measuring the mathematical attitudes of elementary students: The effects of a 4-point or 5-point Likert-type scale. Educational and Psychological measurement, 70(5), 796-807. https://doi.org/10.1177/0013164410366694

[6] Ahmad, T. B. T., Madarsha, K. B., Zainuddin, A. M., Ismail, N. A. H., \& Nordin, M. S. (2010). Faculty's acceptance of computer based technology: Cross-validation of an extended model. Australasian Journal of Educational Technology,26(2). https://doi.org/10. 14742/ajet.1095

[7] Almaiah, M. A., Jalil, M. A., \& Man, M. (2016a). Extending the TAM to examine the effects of quality features on mobile learning acceptance. Journal of Computers in Education, 3(4), 453-485. https://doi.org/10.1007/s40692-016-0074-1

[8] Almaiah, M. A., \& Man, M. (2016). Empirical investigation to explore factors that achieve high quality of mobile learning system based on students' perspectives. Engineering science and technology, an international journal, 19(3), 1314-1320. https://doi.org/10.101 6/j.jestch.2016.03.004

[9] Ajzen, I., \& Fishbein, M. (1980). Understanding attitudes and predicting social behaviour.

[10] Ajzen, I. (1991). The theory of planned behavior. Organizational behavior and human decision processes, 50(2), 179-211. https://doi.org/10.1016/0749-5978(91)90020-t

[11] Alenezi, A. R., Karim, A. M. A., \& Veloo, A. (2011). Institutional support and e-learning acceptance: An extension of the technology acceptance model. International Journal of Instructional Technology and Distance Learning, 8(2), 3-16. 
Paper-Exploring the Key Factors in the Use of an E-Learning System Among Students at King Faisal..

[12] Al-Gahtani, S. S. (2016). Empirical investigation of e-learning acceptance and assimilation: A structural equation model. Applied Computing and Informatics, 12(1), 27-50. https://doi.org/10.1016/j.aci.2014.09.001

[13] Alhabeeb, A., \& Rowley, J. (2017). Critical success factors for eLearning in Saudi Arabian universities. International Journal of Educational Management,31(2), 131-147. https://doi.org/10.1108/ijem-01-2016-0006

[14] Alharbi, H., \& Sandhu, K. (2019). New Discoveries for User Acceptance of E-Learning Analytics Recommender Systems in Saudi Arabia. International Journal of Innovation in the Digital Economy (IJIDE), 10(1), 31-42. https://doi.org/10.4018/ijide.2019010103

[15] Alharbi, H., Sandhu, K., \& Brown, T. (2015, September). The acceptance of e-learning recommender system for Saudi universities: Framework and hypotheses. In Proceedings of the The International Conference on Engineering \& MIS 2015(p. 54). ACM. https://doi.org/10.1145/2832987.2833066

[16] Alharthi, S. H., Awaji, M. H., \& Levy, Y. (2017). Empirical Assessment of the Factors that Influence Instructors' Usage of E-Learning Systems in Saudi Arabia.

[17] Alotaibi, K. J. (2019). Awareness and Usage of E-Learning Materials among Saudi University Students. Engineering And TechnoloandJournal, 4(01), 523-528.

[18] Almaiah, M. A., \& Almulhem, A. (2018a). A conceptual framework for determining the success factors of e-learning system implementation using Delphi technique. Journal of Theoretical and Applied Information Technology, 96(17).

[19] Almaiah, M. A., \& Jalil, M. A. (2014). Investigating Students' Perceptions on Mobile Learning Services. iJIM, 8(4), 31-36.

[20] Almaiah, M. A., Jalil, M. A., \& Man, M. (2016b). PRELIMINARY STUDY FOR EXPLORING THE MAJOR PROBLEMS AND ACTIVITIES OF MOBILE LEARNING SYSTEM: A CASE STUDY OF JORDAN. Journal of Theoretical \& Applied Information Technology, 93(2).

[21] Almaiah, M.A., \& Alamri, M.M (2018). Proposing a new technical quality requirements for mobile learning applications. Journal of Theoretical and Applied Information Technology, 96(19).

[22] Bagozzi, R. P. (2007). The legacy of the technology acceptance model and a proposal for a paradigm shift. Journal of the association for information systems, 8(4), 3 .

[23] BELLAAJ, M., ZEKRI, I., \& ALBUGAMI, M. (2015). THE CONTINUED USE OF ELEARNING SYSTEM: AN EMPIRICAL INVESTIGATION USING UTAUT MODEL AT THE UNIVERSITY OF TABUK. Journal of Theoretical \& Applied Information Technology, 72(3).

[24] Bhuasiri, W., Xaymoungkhoun, O., Zo, H., Rho, J. J., \& Ciganek, A. P. (2012). Critical success factors for e-learning in developing countries: A comparative analysis between ICT experts and faculty. Computers \& Education, 58(2), 843-855. https://doi.org/10.101 6/j.compedu.2011.10.010

[25] Bulman, G., \& Fairlie, R. W. (2016). Technology and education: Computers, software, and the internet. In Handbook of the Economics of Education (Vol. 5, pp. 239-280). Elsevier.

[26] Chang, C. T., Hajiyev, J., \& Su, C. R. (2017). Examining the students' behavioral intention to use e-learning in Azerbaijan? The general extended technology acceptance model for elearning approach. Computers \& Education, 111, 128-143. https://doi.org/10.101 6/j.compedu.2017.04.010

[27] Chen, J. L. (2011). The effects of education compatibility and technological expectancy on e-learning acceptance. Computers \& Education, 57(2), 1501-1511. https://doi.org/10.10 16/j.compedu.2011.02.009 
Paper-Exploring the Key Factors in the Use of an E-Learning System Among Students at King Faisal..

[28] Cheng, Y. M. (2012). Effects of quality antecedents on e-learning acceptance. Internet Research, 22(3), 361-390.

[29] Davis, F. D. (1989). Perceived usefulness, perceived ease of use, and user acceptance of information technology. MIS quarterly, 319-340. https://doi.org/10.2307/249008

[30] Hair, J. F., Anderson, R. E., Babin, B. J., \& Black, W. C. (2010). Multivariate data analysis: A global perspective (Vol. 7).

[31] Fishbein, M., \& Ajzen, I. (1975). Belief, attitude, and behavior: An introduction to theory and research. Reading, Mass.: Addison Wessley.

[32] Islam, A. N. (2013). Investigating e-learning system usage outcomes in the university context. Computers \& Education, 69, 387-399. https://doi.org/10.1016/j.compedu.2013.07.037

[33] Lee, B. C., Yoon, J. O., \& Lee, I. (2009). Learners' acceptance of e-learning in South Korea: Theories and results. Computers \& Education, 53(4), 1320-1329. https://doi.org/10.1 016/j.compedu.2009.06.014

[34] Mohammadi, H. (2015). Investigating users' perspectives on e-learning: An integration of TAM and IS success model. Computers in Human Behavior, 45, 359-374. https://doi.org/10.1016/j.chb.2014.07.044

[35] Naveed, Q. N., Qureshi, M. R. N., Alsayed, A. O., Muhammad, A., Sanober, S., \& Shah, A. (2017, November). Prioritizing barriers of E-Learning for effective teaching-learning using fuzzy analytic hierarchy process (FAHP). In 2017 4th IEEE International Conference on Engineering Technologies and Applied Sciences (ICETAS) (pp. 1-8). IEEE. https://doi.org/10.1109/icetas.2017.8277855

[36] Nickerson, R. S., \& Zodhiates, P. P. (Eds.). (2013). Technology in education: Looking toward 2020. Routledge.

[37] Pachler, N., Bachmair, B., Cook, J., \& Kress, G. (2010). Mobile learning. New York, NY: Springer, 10, 978-1.

[38] Quadri, N. N., Muhammed, A., Sanober, S., Qureshi, M. R. N., \& Shah, A. (2017). Barriers effecting successful implementation of e-learning in Saudi Arabian universities. International Journal of Emerging Technologies in Learning (iJET), 12(06), 94-107. https://doi.org/10.3991/ijet.v12i06.7003

[39] Rosacker, K. M., \& Olson, D. L. (2008). Public sector information system critical success factors. Transforming Government: People, Process and Policy,2(1), 60-70. https://doi.org/10.1108/17506160810862955

[40] Sánchez, R. A., \& Hueros, A. D. (2010). Motivational factors that influence the acceptance of Moodle using TAM. Computers in human behavior,26(6), 1632-1640. https://doi.org/10.1016/j.chb.2010.06.011

[41] Selim, H. M. (2007). Critical success factors for e-learning acceptance: Confirmatory factor models. computers \& Education, 49(2), 396-413. https://doi.org/10.101 6/j.compedu.2005.09.004

[42] Sekaran, U., \& Bougie, R. (2003). Research Methods for Business for a Skill Building Approach, John Willey \& Sons. Inc. New York.

[43] Shawai, Y. G., \& Almaiah, M. A. (2018). Malay Language Mobile Learning System (MLMLS) using NFC Technology. International Journal of Education and Management Engineering, 8(2), 1. https://doi.org/10.5815/ijeme.2018.02.01

[44] Straub, E. T. (2009). Understanding technology adoption: Theory and future directions for informal learning. Review of educational research, 79(2), 625-649. https://doi.org/10.31 02/0034654308325896

[45] ŠUmak, B., HeričKo, M., \& PušNik, M. (2011). A meta-analysis of e-learning technology acceptance: The role of user types and e-learning technology types. Computers in Human Behavior, 27(6), 2067-2077. https://doi.org/10.1016/j.chb.2011.08.005 
Paper-Exploring the Key Factors in the Use of an E-Learning System Among Students at King Faisal..

[46] Surendran, P. (2012). Technology acceptance model: A survey of literature. International Journal of Business and Social Research, 2(4), 175-178.

[47] Tarhini, A., Hone, K. S., \& Liu, X. (2013). Factors affecting students' acceptance of e-learning environments in developing countries: a structural equation modeling approach. https://doi.org/10.7763/ijiet.2013.v3.233

[48] Turner, J. R., \& Müller, R. (2005). The project manager's leadership style as a success factor on projects: A literature review. Project management journal,36(2), 49-61. https://doi.org/10.1177/875697280503600206

[49] Venkatesh, V., Morris, M. G., Davis, G. B., \& Davis, F. D. (2003). User acceptance of information technology: Toward a unified view. MIS quarterly, 425-478. https://doi.org/10.2 $307 / 30036540$

[50] Venkatesh, V., \& Zhang, X. (2010). Unified theory of acceptance and use of technology: US vs. China. Journal of global information technology management, 13(1), 5-27. https://doi.org/10.1080/1097198x.2010.10856507

\section{Author}

Ahmed Al Mulhem is an Assistant professor at Department of Educational Technologies in King Faisal University.

Article submitted 2019-08-26. Resubmitted 2019-10-20. Final acceptance 2019-11-24. Final version published as submitted by the authors. 